raise "Luddite objections" to the technology? If there is a third alternative, I am not the only person who is keen to hear it.

Medical Ethics Committee,

BMA

London WC1H 9JP

\section{Medical audit advisory groups}

\section{Consider the number of practices}

EdrToR,-As Roger Johnson points out, the Department of Health's initial circular about medical audit advisory groups lacked guidance about the specific functions of the groups. ${ }^{1}$ It was perhaps because of this uncertainty that funding allocated to family health services authorities took little account of the number of general practices within each authority. Johnson acknowledges that much of his group's funding is spent on support staff and consumables, the need for which is clearly related to the number of general practitioners whom the group liaises with. For large family health services authorities this results in the amount of funding available to support each practice being much lower than it is in small authorities.

Funding for medical audit in Kent and Manchester Family Health Services Authorities

\begin{tabular}{lrr}
\hline & Kent & Manchester \\
\hline Authority's funding for $1993-4(£)$ & 129000 & 128925 \\
No of practices & 324 & 104 \\
Funding per practice $(€)$ & 398 & 1240 \\
No of general practitioners & 832 & 269 \\
Funding per general practitioner $(€)$ & 155 & 479 \\
\hline
\end{tabular}

The management budget for Kent Family Health Services Authority is proportionately smaller than the budgets for smaller authorities, and there is therefore little scope for the authority to make up funding for Kent's medical audit advisory group to the level of that enjoyed by the Manchester group. Furthermore, there is little opportunity for economies of scale: because of our size we operate as six autonomous groups coordinated by a central committee.

Like Johnson, we have had difficulty in evaluating the cost effectiveness of our activities and so cannot claim that we are underfunded in absolute terms. If medical audit advisory groups in their current form are to continue, however, we think that this inequity in funding should be addressed urgently so that general practices have access to equally funded audit groups irrespective of the size of the family health services authority they practise in.

A J HOWITT

Chairman

CVARNS

Kent Medical Audit Advisory Group, Coordinator

Kent Medical

Kent ME17 1AH

1 Johnson $R$. Where have all the pennies gone? The work of Manchester medical audit advisory group. BMF 1994;309: 98-102. (9 July.)

\section{More investment means better audit yield}

EDITOR,-I endorse Roger Johnson's comments about the difficulty in showing that medical audit advisory groups give value for money, particularly in the short term. ${ }^{1} \mathrm{He}$ correctly emphasises the groups' major role in bringing about a cultural change in general practice to introduce routine critical review; at the same time he identifies the paucity of variables available to measure this change.
I recommend caution, however, in extrapolating from the excellent work reported from Manchester to judge medical audit advisory groups throughout Britain. In terms of basic funding from the family health services authority, in 1992-3 Manchester received a sum equivalent to $£ 1136$ per practice, well above the average allocation of $£ 908$ per practice (though the allocation ranged from $£ 260$ to $£ 2391$ per practice per group) (national survey by Birmingham Medical Audit Advisory Group). In addition, the Manchester group's organisational ability and forward thinking earned it a further $£ 84000$ in externally funded projects in 1992-3: this again is considerably above the average for other groups of $£ 21000$ in that year (range $£ 400$ to $£ 126900)$.

I have little doubt that, at present funding levels, the greater the financial investment the better the audit yield. Pennypinching family health services authorities are likely to obtain poorer value for money from their medical audit advisory groups, which, incidentally, are well on their way to becoming multidsciplinary audit advisory groups.

G HOUGHTON

Chairman, National Primary Care Audit Group

Birmingham Medical Audit Advisory Group, Birmingham B15 2TT

1 Johnson $R$. Where have all the pennies gone? The work of Manchester Medical Audit Advisory Group. BMf 1994;309: 98-102. (9 July.)

\section{Medical history in Paris}

EDITOR,-In his article on three museums of medicine in Paris, Alexander Dorozynski mentions pincers "designed by Ambroise Paré in the 1700s." In fact, Paré was born in 1509 and died in 1590. His life was closely associated with the Valois dynasty of France through Henri II, whom he tried to save from a deep intracranial wound administered by the Count of Montgomery in 1559.

HENRI TAGNON

Fondation Cancer

80 A Avenue Bosveldweg,

1180 Brussels,

Belgium

1 Dorozynski A. 2000 years of medical history in Paris. $B M \mathcal{F}$ 1994;309:546. (20-27 August.)

\section{Overseas Doctors Training Scheme}

EDIToR,-On behalf of the overseas liaison committee of the Royal College of Psychiatrists, we wish to comment on the two recent articles on the Overseas Doctors Training Scheme. ${ }^{12}$ While the authors are rightly critical of past and present deficiencies in training, the picture is far from one of unrelieved gloom

We are concerned that the scheme may be regarded in the same way as the situation facing trainees who are not on college based schemes. More than half of the doctors granted limited registration are on the scheme that exempts doctors from having to take the Professional and Linguistic Assessment Board's examination and are under the watchful eye of the royal colleges; this scheme has made great strides in addressing the training needs of these young doctors. The Intercollegiate Working Group on Overseas Doctors Training has had an important role in advancing this process. We wish to illustrate these positive aspects as they relate to visiting trainee psychiatrists.

At present there are over 100 visiting trainees in psychiatry, and the college accepts responsibility for ensuring that all of them are in approved training rotations for the duration of their stay, not just for finding their first job. Their stay in Britain begins with a one day induction at the college, which provides information on life and work in Britain, clinical practice, and opportunities for academic training and supervision. The induction has always included presentations from resident visiting trainees. We have introduced a yearly trainee forum in association with the college's winter meeting. This is well attended by trainees and tutors. Regular yearly feedback is obtained from both supervising consultants and trainees. It is our impression that the experience for visiting trainee psychiatrists is generally positive. ${ }^{3}$

$$
\begin{array}{r}
\text { F CALDICOTT } \\
\text { President } \\
\text { R J MCCLELLAND } \\
\text { Chairman, overseas liaison committee } \\
\text { JOHN ROBERTSON }
\end{array}
$$

Royal College of Psychiatrists,

London SW1X 8PG

1 Lowry S, Cope H. Postgraduate training for overseas doctors in Britain. BMF 1994;308:1624-7. (18 June.)

2 Richards $T$. The Overseas Doctors Training Scheme: falling expectations. $B M{ }^{f}$ 1994;308:1627-31. (18 June.)

Singh S. Cultural adjustment and the overseas trainee. $B M f$ 1994;308:1169. (30 April.)

\section{Specialists wanted}

EDITOR,-I do not agree with the initiative of the University of Bristol in encouraging doctors with specialist skills to apply for non-medical jobs. ${ }^{1}$ Its advertisement might have been more effective, however, if that for the post of electrician had been placed under the heading "neurology" and that for a plumber under "urology." The placement of an advertisement for a fitter adjacent to that for an orthopaedic surgeon is entirely appropriate.

DAVID F HEWIN

Clinical research fellow

University Department of Surgery,

Bristol Royal Infirmary,

Bristol BS2 8HW

1 BM Classified Advertisements 1994 Sept 10:24.

**This is not an attempt to introduce multiskilling by stealth, just the result of an advertiser's misdirected fax. Red faces for us, but new horizons for our readers?-ED, $B M \mathcal{F}$.

\section{Cigarette advertising}

EDITOR,-For many years tobacco manufacturers have argued against the British Medical Association's call for a ban on tobacco advertising by pretending that such advertising does not encourage young people to start smoking - a line with which the government has colluded. The recent report from the US Centers for Disease Control and Prevention gives impressive proof that teenagers really do buy the most heavily advertised brands. ${ }^{1}$ A spokesperson for the industry was reduced to making a tame allusion to imply that cigarette manufacturers were blameless: "Just as you don't blame General Motors for children who steal cars, nor should you say that cigarette brands initiate kids smoking."

Correct me if I'm wrong, but I don't remember any advertisements enticing children to steal the latest Cavalier. The situation would be comical were it not a matter of life and death.

BMA,

Chairman of coun

London WC1H 9JP

1 Roberts J. US cigarette companies attract young smokers. BMF 1994;309:629-30. (10 September.) 